\title{
Experimental Tests and Analytical Studies of Bearing-Type Axial Steel Connection
}

\author{
Yosafat Aji Pranata*, Noek Sulandari, Roi Milyardi \\ Department of Civil Engineering, Universitas Kristen Maranatha, Indonesia
}

\begin{abstract}
The capacity of the bolted connection on steel tensile rods can be determined through capacity analysis and connection failure. In term of capacity analysis and failure of steel tensile connection, the specified tensile connection capacity is generated based on several parameters such as cross-section of rod, grade of steel, thickness and grade of the steel plate, and grade and diameter of bolts. The capacity of steel tensile connections as a result of capacity analysis and connection failure often has a lower value than the connection capacity in real conditions. In this research, the comparison of $30 \times 30 \times 3 \mathrm{~mm}$ angle cross-section connections with BJ37 grade quality was connected with $2 \mathrm{~mm}$ steel plate (also BJ37 grade) using $8 \mathrm{~mm}$ bolt connectors (A307 grade), through capacity analysis, failure study, and experimental study with type of failure is bolt bearing failure. In the capacity analysis study and the failure of steel tensile connections obtained a nominal capacity is $14.21 \mathrm{kN}$ with the type of failure is shear failure. In the experimental study was tested 3 specimens, the average value of ultimate capacity was $18.67 \mathrm{kN}$ and the failure for all of the three specimens are shear failures. The conclusion that can be drawn from this research is both the result of analytical calculations and experimental testing in the laboratory showed a good agreement and have the same trend. The test specimens were designed on the basis of analytical calculations for bolt bearing failure, experimental test results for all of three specimens all showed a failure pattern of bolt shear. The nominal strength from the results of the analytical study with the ultimate load of the experimental study results has a difference of $31.4 \%$ with higher experimental results. Through this research is expected to be a learning-media to know one type of failure on the steel connections that is bolt shear failure, obtain a comparison between analytical calculation results referring to applicable design standards, and the results of experimental testing in the laboratory.
\end{abstract}

\section{Introduction}

Steel is widely used in the bridge structure, which is specifically a bridge with a type of truss structure as shown in Figure 1. The truss structure transmits axial forces acting like tensile and compressive forces through their components. The rod components that make up the truss are interconnected to each join with the pin type (not holding the moment or shear). The connection between components can be connected using a steel plate (side) and a mechanical connector such as bolt. The axial joint system of the tensile rods of steel comprises several types of failure probabilities, which are tensile, shear (bolt failure), bearing, and block shear types $[1,4,6]$. The type of tensile failure is failure occurs in the drag rod, the type of shear failure is a failure occurs on the bolt, the type of failure of the bearing is a failure occurs due to the bolt effect on the hole connection, as long as the combination of block shear type is a failure occurs in the block shear. The tensile strength of the steel tensile joints can be determined through capacity analysis and connection *Corresponding author: yosafat.ap@eng.maranatha.edu failure, inter alia referring to the regulations of SNI 1729: 2015 [4] or AISC 360-16 [1]. The connectivity capacity is determined based on several structural parameters such as the cross-section type and the grade of steel, the thickness and grade of the connecting plate, and the diameter and grade of the connection bolts. The capacity of steel tensile joint connections resulting from capacity analysis and connection failure often has a lower value than the connection capacity in real conditions.

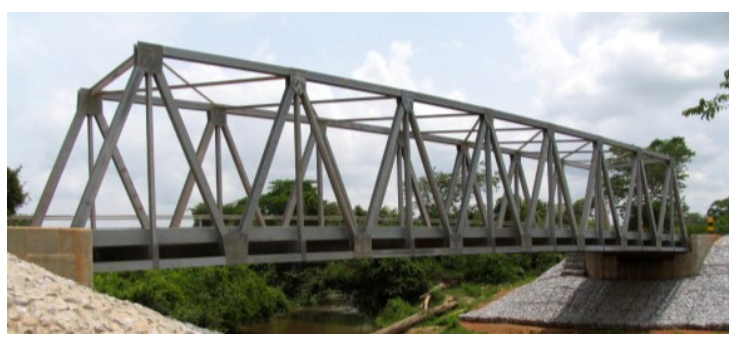

Figure 1 Truss Steel bridge [5]. 
The objective of the study is to study the strength capacity of axial joint of steel tensile connection by analytical method and experimental testing in the laboratory. The scope of the research is the test object that is observed is the axial connection of the pull rod, the loading method is uniaxial tensile, the number of specimens are three specimens, the test using Universal Testing Machine, in analytical calculation used assumption of $240 \mathrm{MPa}$ for yield strength and $370 \mathrm{MPa}$ of ultimate strength, the failure to be observed is the bolt failure on the bolt hole, the cross-section of the steel is the angle L30.30.3, the bolt used is $8 \mathrm{~mm}$ diameter and A307 grade.

\section{Basic Theory}

The analysis of the strength of steel tensile joints using bolts is based on SNI 1729:2015 [4]. The equations that must be met according to the LRFD (Load Resistance Factor Design) or in Indonesian called DFBK (Desain Faktor Beban Ketahanan) method. The strength according to the melting limit of the gross cross section in accordance with SNI 1729: 2015 Chapter D2 (a) (Equation 1).

Which are:

$$
\phi R_{n}=\phi \times F_{y} \times A_{g}
$$
0,90

$\phi=$ resistance factor for tensile yield limit,

$$
\begin{aligned}
& F_{y}=\text { yield strength of steel } \\
& A_{g}=\text { gross cross-section of steel rod }
\end{aligned}
$$

The strength of the pull rod according to the limit of collapse on the net section in accordance with SNI 1729: 2015 Chapter D2 (b) is shown by Equation 2.

Which are:

$$
\phi R_{n}=\phi \times F_{u} \times A_{e}
$$

$\phi=$ resistance factor for tensile ultimate limit,

$F_{u}=$ ultimate strength of steel

$A_{e}=$ net cross-section of steel rod

The effective net width $\left(A_{e}\right)$ is calculated following the provisions of SNI 1729: 2015 Chapter D3, as in Equation (3) and Equation (4).

$$
\begin{gathered}
A_{e}=U \times A_{n} \\
U=1-x / 1
\end{gathered}
$$

Which are:

$$
\begin{aligned}
U & =\text { shear lag factor } \\
x & =\text { excentricity of connection } \\
l & =\text { length of connection }
\end{aligned}
$$

The net width of the trunk section cross section $\left(A_{n}\right)$ is calculated following the provisions of SNI 1729: 2015 Chapter B4.3, which can be written as Eq. (5). Which are:

$$
A_{n}=A_{g}-n \times d \times t
$$

$n$ = number of bolt in the line of tensile failure

$d=$ hole diameter for net cross-section of tensile rod

$t=$ thickness of plate
The strength of the bolt shear at the pivot type connection, according to SNI 1729:2015 Chapter J3.6 is shown by Equation 6 .

Which are:

$$
\phi R_{n}=\phi \times F_{n v} \times A_{b}
$$

$$
\begin{aligned}
& \phi=\text { resistance factor for shear of bolt } 0.75 \\
& F_{n v}=\text { nominal shear stress of bolt } \\
& A_{b}=\text { nominal cross-section of bolt }
\end{aligned}
$$

The strength of the bolt hole $\left(\phi R_{n}\right)$, according to SNI 1729:2015 Chapter J3.10 (a) is shown by Equation 7.

Which are:

$$
R_{n}=1.2 \times l_{c} \times \mathrm{t} \times F_{u} \leq 2,4 \times d_{b} \times \mathrm{t} \times F_{u}
$$
strength 0.75

$$
\phi=\text { resistance factor in term of bearing }
$$

$l_{c}=$ clear distance hole to hole

$d_{b}=$ bolt diameter

The shear strength of the block $\left(\phi R_{n}\right)$ on the steel rod joints, in accordance with SNI 1729:2015 Chapter $\mathrm{J} 4.3$ is shown by Equation 8 .

$$
R_{n}=0.6 \times F_{u} \times A_{n v}+U_{b s} \times F_{u} \times A_{n t} \leq 0.6 \times F_{y} \mathrm{x}
$$

$A_{g v}+U_{b s} \times F_{u} \times A_{n t}$

Which are:

0,75

$$
\phi=\text { resistance factor in term of block shear }
$$

$A_{n t}=$ tensile net area

$A_{n v}=$ shear net area

$R_{n}$

$A_{g v}=$ gross area

$U_{b s}=$ reduction coefficient for block shear failure

Experimental tests of tensile strength of tensile bars are based on ASTM E8 / E8M - 16a Standard Test Methods for Tension Testing of Metallic Materials (ASTM, 2016) with a crosshead test rate of 0.015 $\mathrm{mm} / \mathrm{mm} / \mathrm{min}$. Figure 2 shows the Universal Testing Machine (UTM) used for experimental testing.

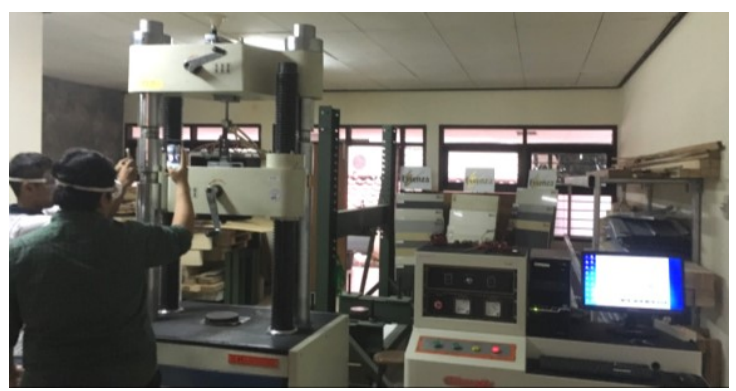

Fig. 2. Universal Testing Machine for tensile testing of steel joints.

\section{Case Study}

In this study, the steel tensile beam test of (the elbow profile is equal to the quality foot $\mathrm{BJ}-37$ size $30 \times 30 \times 3 \mathrm{~mm}$ spliced with BJ-37 thickness steel plate 3 mm using A307 diameter bolt $8 \mathrm{~mm}$ diameter which has the connection configuration as shown in Figure 3. With the configuration of steel tie rod connections such as shown in Figure 2, two models of study were studied: an analytical study of the strength of steel 
tapered joints using bolts according to the DFBK method determined by SNI 1729:2015 and experimental studies of steel tensile joints testing using bolts in the laboratory.

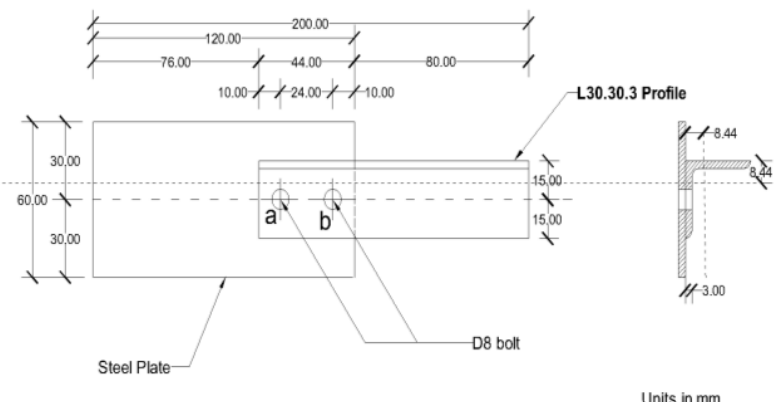

Fig. 3. Configuration of axial tensile steel connection

\subsection{Analytical Study}

The strength of the angle (L) rod according to the yield and the ultimate limits calculated according to Equation 1 to Eq. 5, the following results are obtained: Strength of the stem according to the melting limit conditions:

$$
\phi R_{n}=0.90 \times F_{y} \times A_{g}=37303 \mathrm{~N}
$$

The strength of the stem according to the boundary condition of pull collapse:

$$
\phi R_{n}=0.75 \times F_{u} \times A_{e}=24594 \mathrm{~N}
$$

The strength of the bolt shear at the base-type connection is calculated according to Equation 6, with the following results: Sliding strength of connection using 2 pieces of bolts:

$$
\phi R_{n}=0.75 \times \text { n }_{\text {baut }} \times F_{n v} \times A_{b}=18900 \mathrm{~N}
$$

The strength of the bolt hole base is calculated according to Equation 7. For this calculation it is necessary to determine the net distance (lc) between the edges of the bolt a to the edge of the tied rod and the edge of the bolt $\mathrm{a}$ and bolt $\mathrm{b}$ as shown in Figure 3 .
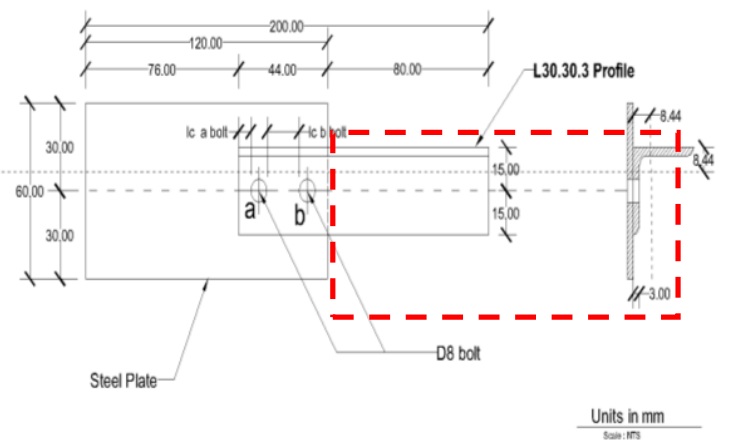

Fig. 4. Determine the clear distance $\left(l_{c}\right)$ hole to hole of bolts

The strength of the bolt hole:

\begin{tabular}{|l|r|r|r|r|r|r|r|}
\multicolumn{7}{|c|}{$R_{n}=1.2 \times l_{c} \times \mathrm{t} \times F_{u} \leq 2.4 \times d_{b} \times t \times F_{u}$} \\
\hline bolt & & & 1420 & & $\mathrm{R}_{\mathrm{na}}$ & & \\
a: & 3552 & $\leq$ & 8 & $\rightarrow$ & $=$ & 3553 & $\mathrm{~N}$ \\
\hline boltt & 1065 & & 1420 & & $\mathrm{R}_{\mathrm{nb}}$ & 1065 & \\
b: & 6 & $\leq$ & 8 & $\rightarrow$ & $=$ & 6 & $\mathrm{~N}$ \\
\hline
\end{tabular}

\begin{tabular}{|l|l|r|l|l|l|l|l|} 
so: & $\mathrm{R}_{\mathrm{n}}=$ & $\begin{array}{r}\mathrm{R}_{\mathrm{na}}+ \\
\mathrm{R}_{\mathrm{nb}}\end{array}$ & & & & & \\
\hline & & & $\mathrm{N}$ & & & & \\
& $\mathrm{R}_{\mathrm{n}}=$ & 14208 & $\mathrm{~N}$ & & & \\
\hline
\end{tabular}

The shear strength of the steel tank trunk connection joints is calculated according to Equation 8 . The determination of the sliding block area is shown in Figure 4.

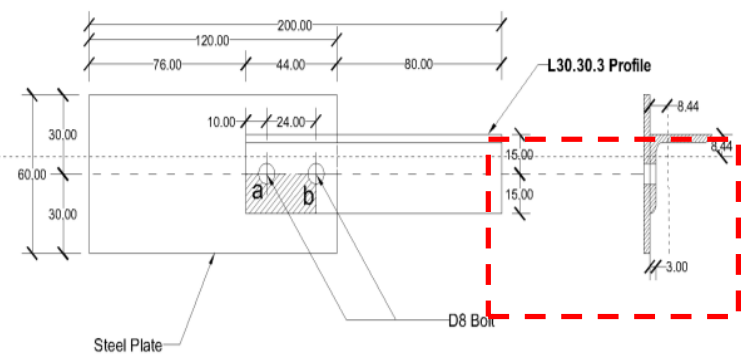

Units in mm

Fig. 5. Determining the block shear

Block shear strength:

$$
R_{n}=0.6 \times F_{u} \times A_{n v}+U_{b s} \times F_{u} \times A_{n t} \leq 0.6 \times F_{y} \mathrm{x}
$$

$A_{g v}+U_{b s} \times F_{u} \times A_{n t}$

\begin{tabular}{|l|c|c|c|c|}
\hline Fracture: & $\begin{array}{c}0.6 \times \mathrm{F}_{\mathrm{u}} \times \mathrm{A}_{\mathrm{nv}}+\mathrm{U}_{\mathrm{bs}} \times \mathrm{F}_{\mathrm{u}} \mathrm{x} \\
\mathrm{A}_{\mathrm{nt}}\end{array}$ & $=20646$ & $\mathrm{~N}$ \\
\hline Yield: & $\begin{array}{c}0.6 \times \mathrm{F}_{\mathrm{y}} \times \mathrm{A}_{\mathrm{gv}}+\mathrm{U}_{\mathrm{bs}} \times \mathrm{F}_{\mathrm{u}} \mathrm{x} \\
\mathrm{A}_{\mathrm{nt}}\end{array}$ & $=24678$ & $\mathrm{~N}$ \\
\hline
\end{tabular}

The smallest value that determines, so $R_{n}=20646 \mathrm{~N}$ and $\phi \mathrm{R}_{\mathrm{n}}=15485 \mathrm{~N}$.

Table 1. Strength/Capacity of Steel Axial Connection

\begin{tabular}{|l|c|c|c|}
\hline \multicolumn{1}{|c|}{ Analysis } & $\boldsymbol{\phi} \mathbf{R}_{\mathbf{n}} \mathbf{( k N )}$ & $\begin{array}{c}\mathbf{R}_{\mathbf{n}} \\
(\mathbf{k N})\end{array}$ & Summary \\
\hline Yield Tensile Strength & 37.30 & 41.45 & - \\
\hline Ultimate Tensile Strength & 24.59 & 32.79 & - \\
\hline Bolt Shear Strength & 18.90 & 25.20 & - \\
\hline Bearing Strength & 10.66 & 14.21 & Critical \\
\hline Block Shear Strength & 15.49 & 20.65 & - \\
\hline
\end{tabular}

The summary of the tensile steel tie connection capacity is shown in Table 1, which is based on the analytical calculation of the capacity of the melting yield limit, the ultimate strength, the bolt strength, the bolt hole or bearing strength, and the block shear strength. From the analytical study, the configuration of the joints in this study as shown in Figure 1 has a limit of $14.21 \mathrm{kN}$ (without $\phi$ ).

\subsection{Experimental Study}

In the experimental study testing of steel tensile joints were prepared 3 specimens according to the configuration of Figure 1. Tensile tests were performed using Universal Testing Machine (UTM). On specimens welded a special clamp of stainless-steel material to ensure the steel connection receives an axial 
force optimally as shown in Figure 6. Before tensile testing begins, the three test objects are erect on the bolts so that all trimmed steel rod joint elements can work optimally to load. The initial conditions of the three test pieces of steel tug joints are shown in Figure 6 . Tensile testing is performed on each connection with axial force axial force of $5 \mathrm{~mm} / \mathrm{min}$ until each specimen fails due to the axial force of attraction received. The tensile test results are shown in Figure 7.

In Figure 8, the three specimens experience a failure on the plate according to the predicted of the analytical study. Tensile test result, obtained load curve to deformation (P-D curve). From the P-D curve we get the proportional limit load value $\left(\mathrm{P}_{\mathrm{y}}\right)$ and the ultimate load value $\left(\mathrm{P}_{\mathrm{u}}\right)$ of the steel tensile bearing test specimen shown in Figure 9 and Table 2.

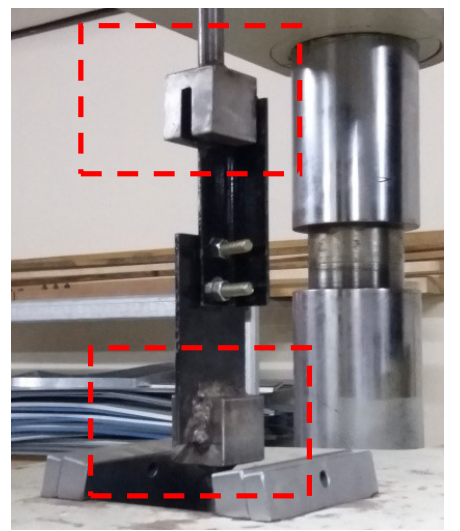

Fig. 6. Setup of specimen on Universal Testing Machine (UTM)

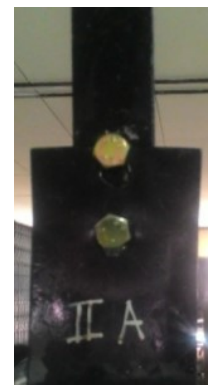

(a) Specimen 1

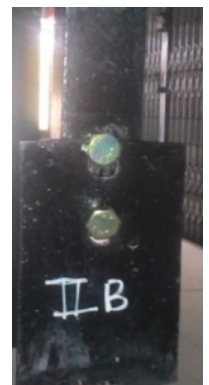

(b) Specimen 2

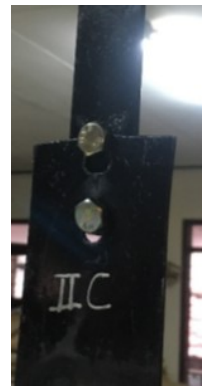

(c) Specimen 3
Figure 7 All of 3 (three) specimens.
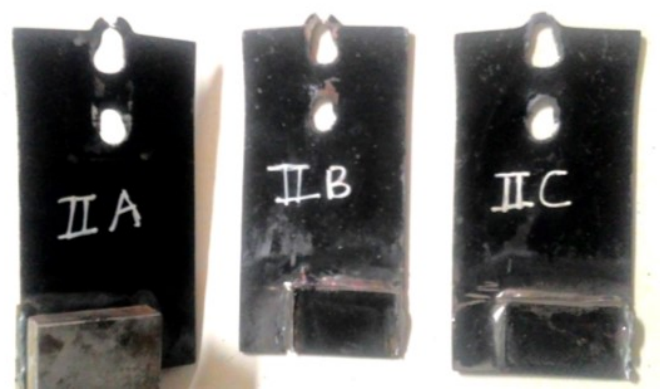

(a) Specimen 1 (b) Specimen 2 (c) Specimen 3

Fig. 8. Failure of 3 (three) specimens
From Table 2 we get the average value of the three test pieces of steel tug joints. For a proportional limit load $\left(\mathrm{P}_{\mathrm{y}}\right)$ of $12872.33 \mathrm{~N}$ and for ultimate load $\left(\mathrm{P}_{\mathrm{u}}\right)$ of 18669.33 N. Design limit $\left(R_{n}\right)$ of analytical study results of $14.21 \mathrm{kN}$ or $14208 \mathrm{~N}$ (without $\phi$ ). When compared with the ultimate load value of the experimental $\left(\mathrm{P}_{\mathrm{u}}\right)$ experimental results on average of 3 (three) specimens is $18669.33 \mathrm{~N}$ means that the experimental study results have $31.40 \%$ greater value.

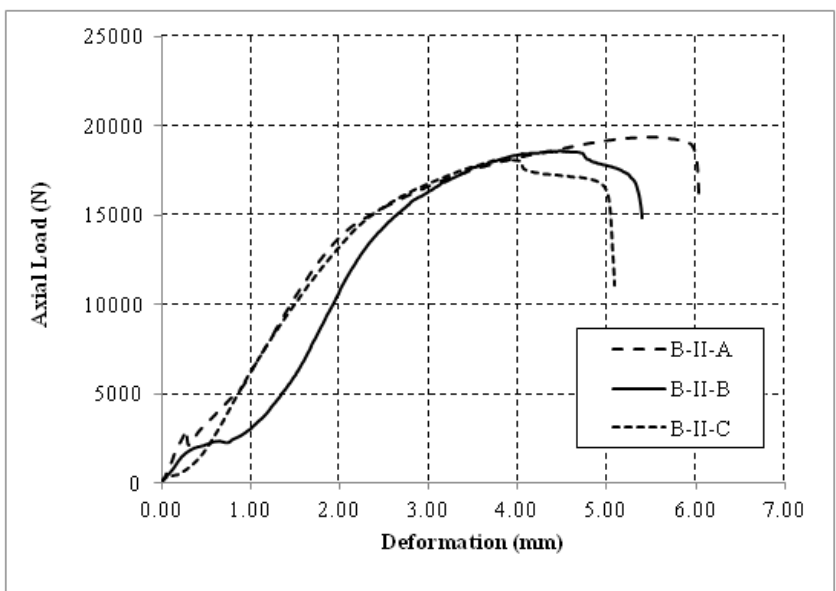

Fig. 9. P-D curves of Steel Axial Connection Specimen

Table 2 Results of Proportional $\left(\mathrm{P}_{\mathrm{y}}\right)$ and Ultimate $\left(\mathrm{P}_{\mathrm{u}}\right)$ Loads

\begin{tabular}{|c|c|c|c|c|}
\hline $\begin{array}{c}\text { Specime } \\
\mathbf{n}\end{array}$ & $\mathbf{P}_{\mathbf{y}} \mathbf{( N )}$ & $\begin{array}{c}\mathbf{D}_{\mathbf{y}} \\
(\mathbf{m m})\end{array}$ & $\mathbf{P}_{\mathbf{u}} \mathbf{( N )}$ & $\begin{array}{c}\mathbf{D}_{\mathbf{u}} \\
(\mathbf{m m})\end{array}$ \\
\hline B-II-A & $\begin{array}{c}11565.4 \\
2\end{array}$ & 1.65 & $\begin{array}{c}19376.3 \\
6\end{array}$ & 5.47 \\
\hline B-II-B & $\begin{array}{c}15231.9 \\
4\end{array}$ & 2.70 & $\begin{array}{c}18581.7 \\
9\end{array}$ & 4.48 \\
\hline B-II-C & $\begin{array}{c}11819.6 \\
4\end{array}$ & 1.77 & $\begin{array}{c}18049.8 \\
3\end{array}$ & 3.86 \\
\hline Average & $\begin{array}{c}12872.3 \\
3\end{array}$ & 2.04 & $\begin{array}{c}18669.3 \\
3\end{array}$ & 4.60 \\
\hline
\end{tabular}

\section{Conclusion}

The conclusions that can be obtained from this research are both the result of analytical calculations and experimental testing in the laboratory showed a good agreement and the same trend. The test specimen was designed on the basis of analytical calculations for bolt bearing failure, experimental test results for 3 (three) test specimens all showed a failure pattern of bolt shear. The nominal strength of the analytical study with the ultimate load of the experimental study results has a difference of $31.4 \%$ with higher experimental results. Through this research is expected to be a learning-media to know one type of failure on the steel connections that is bolt shear failure, obtain a comparison of analytical calculation results referring to applicable planning standards and the results of experimental testing in the laboratory. 


\section{References}

1. American Institute of Steel Construction, ANSI/AISC 360-16, Specification for Structural Steel Buildings, American Institute of Steel Construction, (2016).

2. American Society for Testing and Material, ASTM E8/E8M-16a Standard Test Methods for Tension Testing of Metallic Materials, American Society for Testing and Material, (2016).

3. W. Dewobroto, Struktur Baja Perilaku, Analisis dan Desain - AISC 2010 Edisi ke-2, Penerbit Jurusan Teknik Sipil UPH, Tangerang (in Indonesian), (2016).
4. Badan Standardisasi Nasional, SNI 1729:2015 Spesifikasi Untuk Bangunan Gedung Baja Struktural, Badan Standardisasi Nasional, Jakarta (in Indonesian), (2015).

5. W.T. Segui, Steel Design, 6th Edition, (Cengage Learning, 2018)

6. N. Sulandari, R. Milyardi, Y.A. Pranata, Studi Eksperimental dan Analitis Kapasitas Sambungan Baja Batang Tarik dengan Tipe Kegagalan Geser Baut, Jurnal Teknik Sipil, Volume 13 Nomor 1 (in Indonesian), (2017).URL: http://www.dijkstaal.nl/en/projects/steelbridges/modular-steel-truss-bridges. 